\title{
Health Status of Elderly People Living in Old Aged Homes in Pokhara
}

\author{
*Ananta Raj Dhungana ${ }^{1}$, Parbati Dhungana ${ }^{2}$ \\ ${ }^{1}$ School of Development and Social Engineering, Pokhara University \\ ${ }^{2}$ Pokhara Academy of Health Science, Western Regional Hospital, Pokhara, Nepal
}

*Corresponding Author: Dr. Ananta Raj Dhungana; Email: anantastat@gmail.com

\begin{abstract}
Background: Health is serious matter for the elderly people especially living in old aged homes. In this context, this study has tried to explore the health status of elderly people living in old aged homes.

Methods: Information were collected from fifty seven elderly people living in purposively selected three major old aged homes of Pokhara by using structured questionnaire through interview techniques. The elderly people, who were unable to speak, hear, complete the interview process, have severe psychiatric disorder, did not have verbal consent to participate were excluded from the study. Descriptive analysis was carried out for this research.

Results: Majority (87.7\%) of the respondents had chronic physical health problem like back pain problem as major followed by other musculoskeletal problems, gastrointestinal disease, hypertension, respiratory problem, diabetes mellitus, heart disease, eyes and ears problem. The proportion of female was higher than male regarding their chronic physical health problem. Majority went to hospital when they were sick. Half of the respondents were worried about economic insecurity followed by lack of social relation, lack of treatment during illness, fear of future, lack of recreational activities, food management of old age homes, environment of elderly official, sitting and sleeping environment of elderly home and others respectively. All the respondents prayed god to cope with these stress followed by listening to religious hymns, go to religious places, solitary living, crying alone, and take cigarettes/alcohols.

Conclusions: Health status of elderly people living in old aged home was not good since most of the elderly were suffered from chronic physical health problem. Females are more vulnerable.
\end{abstract}

Keywords: Elderly People, health condition, old aged home, religious, stress

\begin{tabular}{|l|l|l|}
\hline \multicolumn{2}{|c|}{ Access this article Online } & \multicolumn{1}{c|}{ Article Info. } \\
Quick Response Code & \multicolumn{1}{|c|}{ Website: } & \multicolumn{1}{c|}{ How to cite this article in Vancouver Style? } \\
\hline & www.jkahs.org.np & $\begin{array}{l}\text { Dhungana A, Dhungana P. Health Status of Elder- } \\
\text { ly People Living in Old Aged Homes in Pokhara. } \\
\text { Journal of Karnali Academy of Health Sciences } \\
\text { 2020;3(2): 28-35 }\end{array}$ \\
\hline
\end{tabular}




\section{INTRODUCTION}

Old aged homes are the places which provide food and shelter for the elderly people. Some of those elders are discarded by their sons because they are very old to be taken care of and some of those elders may not have children or relatives to live with ${ }^{1}$. There are many old aged homes in Nepal where the elderly people of ages 60 and above live the remaining days of their lives. ${ }^{1}$ According to the 2001 census of $\mathrm{Nepal}^{2}$, its elderly population constituted $6.5 \%$ of the total population of the country. During the years 1991-2001, the annual elderly population growth rate was $3.39 \%$ as against the national population growth rate of $2.3 \% .{ }^{3,4}$ According to the 2011 census $^{5}$, the percentage of elderly population has increased to 8.13 percent.

Ageing is a normal process, which is associated with physical, social and psychological changes. The number of older population of both developed and developing countries has considerably increased in the 20th century. Previous studies conducted in Nepal reveal that the tradition of Nepalese peoples respecting their parents and elder is gradually declining. There is an obligation among young generation to leave their home for searching employment and opportunities of good education. This process is continuing in all parts of the country due to which huge number of senior citizens are compelled to live alone in their usual place of residence. Thus the elderly populations are highly susceptible to mental, psychological and several physical problems. ${ }^{6}$

Due to the demands of the modern cash economies, most children and grandchildren do not stay with their older members of the family and as such the family members are unavailable to assist such older persons. Consequently, many older people are lonely and have limited opportunities for interaction. This is exacerbated by the lack of facilities, such as day care centers and recreational facilities. ${ }^{7}$

The importance of care that has to be given to the geriatric population is big issues emphasized by many studies in Nepal and abroad. The comparative study concluded that depression was the most common psychiatric disorder in the general population $(21.7 \%)$ and also in those living in old age homes (25\%), followed by anxiety disorders $(5.8 \%){ }^{8}$
Age, gender, living arrangement, marital status, education, occupation, family type and economy dependency, living condition were found associated with the depression of elderly people. ${ }^{9}$

Elderly who died of suicide and had a past history of suicidal behavior were more likely to suffer from depression. ${ }^{10}$

Similarly, the different studies in Ludhiana, India and Iran revealed that economic status, social relations, unhappiness with old age, absence of friendly activities within the households, behavior of family members, loneliness and feelings of neglect were found to be statistically significant factors for anxiety, depression and allied health problems. ${ }^{11,12}$

Overall, depression was found in 51.1 percent among study population. Depression was more among nonreligious $(60.61 \%)$ and among those who were not involved in any extrinsic or intrinsic religious activity. ${ }^{13}$

There is direct or indirect effect of the physical health status of elderly people, their mind diversional activities, their worries and copying strategies to the depression of the elderly. So, there is need of doing such research to know the status of elderly people regarding these factors. In this context, this study has tried to explore the health status of elderly people living in old aged homes of Pokhara.

\section{MATERIALS AND METHODS}

Cross-sectional research design was adopted for this study. At first, three major old aged homes in Pokhara i.e. Pokhara Aged Shelter having 50 elderly people located at Pokhara-17, Sitapaila, Batsyayan Aged Shelter having 15 elderly people located at Pokhara-18, Batchchibuduwa, and Radha Krishna Senior Citizen Residence having 45 elderly people located at Pokhara-32, Tallo Gagangauda were selected purposively. So, there were altogether 110 elderly people with age 60 years and above in these old aged homes. At second stage, the elderly people, who were unable to speak, hear, complete the interview process, have severe psychiatric disorder, did not have verbal consent to participate in this study were excluded from the study. Finally, data was collected from all the fifty seven respondents i.e. 22 respondents from Pokhara Aged Shelter, 24 respondents of Radha Krishna Senior Citizen Residence, and 11 respondents of Batsyayan 
Aged Shelter who met the criteria of the respondents by using structured questionnaire through interview techniques. The data was collected during March and April of 2019 A. D. Descriptive analysis was carried out for this research.

\section{RESULTS}

Majority (43.9\%) of the respondents had been staying in old aged homes since more than 1 to 5 years followed by above 5 years (40.4\%) and upto one year $(15.8 \%)$. Minimum duration of stay was 6 months and maximum was 16 years. Average duration of stay was 5.8 years with standard deviation 4.6 years (Figure 1).

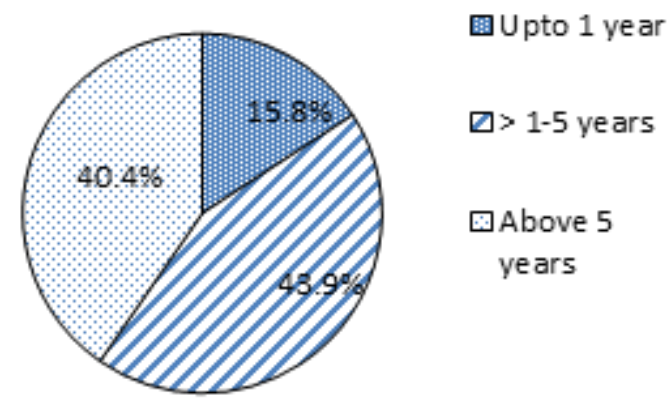

Most (87.7\%) of the respondents had CPHP. Further, out of 50 respondents having CPHP, more than four fifth $(82 \%)$ of the respondents were suffering from back pain problem followed by other musculoskeletal problem (74\%), gastrointestinal disease (74\%), hypertension (46\%), respiratory problem $(36 \%)$, diabetes mellitus (36\%), heart disease $(26 \%)$ and other physical health problems (8\%) like eyes problems and ears problem. More than three fourth $(77.2 \%)$ of the respondents responded that they visited hospital when they were sick. Almost three fifth $(59.6 \%)$ of the respondents were involved in the regular checkup in elderly home when they were sick whereas very few $(7 \%)$ of the respondents responded that they bought medicine from drug house when they were sick (Table 1).

Figure 1: Duration of Stay

Table 1: Chronic Physical Health Problems (CPHP) of Respondents

\begin{tabular}{|l|c|c|}
\hline \multicolumn{2}{|c|}{ Variables } & Number \\
\hline CPHP & 50 & 87.7 \\
\hline Yes & 7 & 12.3 \\
\hline No & 41 & \\
\hline Types of Physical Health Problem $(\mathrm{N}=50)^{*}$ & 37 & 82.0 \\
\hline Back pain & 37 & 74.0 \\
\hline Other musculoskeletal problem & 23 & 74.0 \\
\hline Gastrointestinal disease & 18 & 46.0 \\
\hline Hypertension & 18 & 36.0 \\
\hline Respiratory problem & 13 & 36.0 \\
\hline Diabetes mellitus & 4 & 26.0 \\
\hline Heart disease & & 8.0 \\
\hline Others & 34 & 59.6 \\
\hline Way of Treatment while ill (N=50)* & 4 & 7.0 \\
\hline Regular checkup in elderly home & & 77.2 \\
\hline $\begin{array}{l}\text { Bringing medicine from drug house when } \\
\text { ill }\end{array}$ & 44 & \\
\hline Going Hospital & & \\
\hline
\end{tabular}

\section{*Based on Multiple Responses}


The proportion of female was higher regarding the chronic physical health problem than the male. Further the proportion of female was also higher than male in case of all the types of chron- ic physical health problem like back pain, other musculoskeletal problems, gastrointestinal disease, hypertension, respiratory problem, diabetes mellitus and heart disease (Table 2).

Table 2: Chronic Physical Health Problem by Sex

\begin{tabular}{|c|c|c|c|c|c|c|}
\hline \multirow[b]{3}{*}{ Variables } & \multicolumn{4}{|c|}{ Sex } & \multirow{2}{*}{\multicolumn{2}{|c|}{ Total }} \\
\hline & \multicolumn{2}{|c|}{ Male } & \multicolumn{2}{|c|}{ Female } & & \\
\hline & Number & Percent & Number & Percent & Number & Percent \\
\hline \multicolumn{7}{|c|}{ Chronic Physical Health Problem } \\
\hline No & 4 & 7.0 & 3 & 5.3 & 7 & 12.3 \\
\hline Yes & 16 & 28.1 & 34 & 59.6 & 50 & 87.7 \\
\hline \multicolumn{7}{|l|}{ Back pain } \\
\hline No & 8 & 14.0 & 8 & 14.0 & 16 & 28.1 \\
\hline Yes & 12 & 21.1 & 29 & 50.9 & 41 & 71.9 \\
\hline \multicolumn{7}{|c|}{ Other musculoskeletal Problems } \\
\hline No & 9 & 15.8 & 11 & 19.3 & 20 & 35.1 \\
\hline Yes & 11 & 19.3 & 26 & 45.6 & 37 & 64.9 \\
\hline \multicolumn{7}{|c|}{ Gastrointestinal disease } \\
\hline No & 10 & 17.5 & 10 & 17.5 & 20 & 35.1 \\
\hline Yes & 10 & 17.5 & 27 & 47.4 & 37 & 64.9 \\
\hline \multicolumn{7}{|c|}{ Heart Disease } \\
\hline No & 17 & 29.8 & 27 & 47.4 & 44 & 77.2 \\
\hline Yes & 3 & 5.3 & 10 & 17.5 & 13 & 22.8 \\
\hline \multicolumn{7}{|l|}{ Hypertension } \\
\hline No & 10 & 17.5 & 24 & 42.1 & 34 & 59.6 \\
\hline Yes & 10 & 17.5 & 13 & 22.8 & 23 & 40.4 \\
\hline \multicolumn{7}{|c|}{ Respiratory Problem } \\
\hline No & 14 & 24.6 & 25 & 43.9 & 39 & 68.4 \\
\hline Yes & 6 & 10.5 & 12 & 21.1 & 18 & 31.6 \\
\hline \multicolumn{7}{|c|}{ Diabetes Mellitus } \\
\hline No & 15 & 26.3 & 24 & 42.1 & 39 & 68.4 \\
\hline Yes & 5 & 8.8 & 13 & 22.8 & 18 & 31.6 \\
\hline
\end{tabular}

Almost two fifth $(38.6 \%)$ of the respondents took bath daily in elderly home followed by once a week $(31.6 \%)$, twice a month $(14 \%)$, twice a week $(8.8 \%)$ and once a month (7\%) respectively. More than two thirds $(69.6 \%)$ of the respondents drank water directly from tap followed by boiled (36.4\%), euro guard (23.6\%), mineral/jar $(23.6 \%)$ and filtered water $(16.4 \%)$. More than four fifth $(82.5 \%)$ of the respondents washed their clothes themselves where as 14 percent respondents' clothes were washed by the staff of elderly home followed by their family members $(3.5 \%)$. More than four fifth $(82.5 \%)$ of the respondents responded that there was availability of the caregivers. The types of caregiver were the staff of the elderly home. More than three fifth $(61.7 \%)$ of the respondents were feeling the need of caregivers to look after them (Table 3). 
Table 3: Drinking Water, Bathing, Cloth Washing and Caregivers $(\mathbf{N}=57)$

\begin{tabular}{|c|c|c|}
\hline \multicolumn{2}{|c|}{ Variables } & Percent \\
\hline \multicolumn{3}{|l|}{ Bathing Status } \\
\hline Daily & 22 & 38.6 \\
\hline Once a week & 18 & 31.6 \\
\hline Twice a week & 5 & 8.8 \\
\hline Twice of month & 8 & 14.0 \\
\hline Once a month & 4 & 7.0 \\
\hline \multicolumn{3}{|l|}{ Types of Water* } \\
\hline Directly from tap & 39 & 69.6 \\
\hline Filtered water & 9 & 16.4 \\
\hline Euro guard & 13 & 23.6 \\
\hline Mineral/Jar & 13 & 23.6 \\
\hline Boiled & 20 & 36.4 \\
\hline \multicolumn{3}{|c|}{ Persons for Washing Clothes } \\
\hline Self & 47 & 82.5 \\
\hline Family members & 2 & 3.5 \\
\hline Staff of elderly home & 8 & 14.0 \\
\hline \multicolumn{3}{|l|}{ Availability of Caregivers } \\
\hline No & 10 & 17.5 \\
\hline Yes & 47 & 82.5 \\
\hline \multicolumn{3}{|c|}{ Feeling the Need of Care Givers $(\mathrm{N}=47)$} \\
\hline No & 18 & 38.3 \\
\hline Yes & 29 & 61.7 \\
\hline
\end{tabular}

\section{* Based on Multiple Response}

Majority $(59.6 \%)$ of the respondents were worried regarding old aged homes. Out of 34 respondents who were worried about old aged homes, half (50\%) of respondents were worried regarding economic insecurity followed by distance of social network (47.1\%), treatment during illness (44.1\%), anxiety of future life $(23.5 \%)$, recreational activities $(23.5 \%)$, food management of elderly homes $(5.9 \%)$, the environment of elderly official (5.9\%), sitting and sleeping environment of old aged homes $(2.9 \%)$ and others $(2.9 \%)$ respectively (Table 4$)$.

\section{Table 4: Worries in Old Aged Home}

\begin{tabular}{|l|l|l|}
\hline \multicolumn{1}{c}{ Variables } & \multicolumn{1}{c|}{ Number } & \\
\hline Worries & 34 & 59.6 \\
\hline Yes & 23 & 40.4 \\
\hline No & \multicolumn{2}{l|}{} \\
\hline Kinds of Worries $(\mathrm{N}=34)^{*}$ & 8 & 23.5 \\
\hline Anxiety of future life & & \\
\hline
\end{tabular}




\begin{tabular}{|l|l|l|}
\hline Food management of elderly homes & 2 & 5.9 \\
\hline Lack of entertainment & 8 & 23.5 \\
\hline Economic insecurity & 17 & 50 \\
\hline Distance of Social network & 16 & 47.1 \\
\hline Sitting and sleeping Environment of old aged home & 1 & 2.9 \\
\hline Environment of elderly home official & 2 & 5.9 \\
\hline Treatment during illness & 15 & 44.1 \\
\hline Others & 1 & 2.9 \\
\hline
\end{tabular}

\section{* Based on Multiple Responses}

More than two fifth (43.9\%) of the respondents were feeling stress while staying in old aged home. Out of 25 respondents who were feeling stress, all of them said that they often prayed god to cope with these stress followed by listening to religious hymns (88\%), listening religious speech $(80 \%)$, visit to religious places (68\%), solitary living (44\%), shares the feelings with mates (40\%), crying alone (32\%), and take cigarettes/alcohols (24\%) respectively (Table 5).

\section{Table 5: Feeling of Stress and Coping Strategies}

Characteristics Frequency
\begin{tabular}{|l|l|l|}
\hline Feeling of Stress \\
\hline No & 32 & 56.1 \\
\hline Yes & 25 & 43.9 \\
\hline Coping Strategies (N=25)* \\
\hline Visit to religious places & 17 & 68.0 \\
\hline $\begin{array}{l}\text { Listening to religious } \\
\text { hymns }\end{array}$ & 22 & 88.0 \\
\hline Solitary living & 11 & 44.0 \\
\hline Pray to god & 25 & 100.0 \\
\hline $\begin{array}{l}\text { Listening religious } \\
\text { speech }\end{array}$ & 20 & 80.0 \\
\hline $\begin{array}{l}\text { Shares the feelings with } \\
\text { mates }\end{array}$ & 10 & 40.0 \\
\hline Crying alone & 8 & 32.0 \\
\hline Take cigarettes/alcohols & 6 & 24.0 \\
\hline
\end{tabular}

\section{* Based on Multiple Responses}

More than four fifth $(80.7 \%)$ of the respondents responded that they had different types of mind diversional activities launched by the elderly home. These activities involved religious activities like
Bhajan Kirtan and religious storytelling and the elderly homes arranged the different types of activities like visit to religious places, celebration of festivals, celebration of birthday ceremony of different people coming to the elderly home which helped to divert their mind (Figure 2).

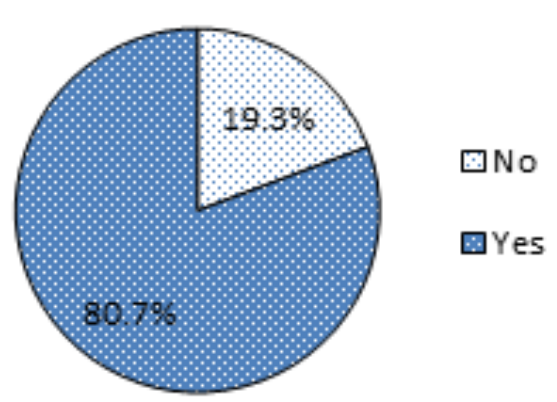

Figure 2: Mind Diversional Activities ( $N=57)$

\section{DISCUSSION}

Healthisserious matter fortheelderly peopleespecially living in old aged homes. So there is need to explore the health condition of these people. In this context, this study has tried to explore the health condition of elderly people living in these homes. Majority of the respondents had chronic physical health problem like back pain problem as major followed by other musculoskeletal problems, gastrointestinal disease, hypertension, respiratory problem, diabetes mellitus, heart disease and other physical health problems like eyes problems and ears problem. This result is similar to the study done by Dhungana and Kleisiaris et al. ${ }^{14,15}$. The study in Bangladesh shows that $87.7 \%$ of the elderly were suffering from one or more diseases which is similar to the result of this study. ${ }^{16}$ 
The proportion of female was higher regarding the chronic physical health problem than the male. Further the proportion of female was also higher than male in case of all the types of chronic physical health problem like back pain, other musculoskeletal problem, gastrointestinal disease, hypertension, respiratory problem, diabetes mellitus and heart disease. So, female are more vulnerable than male regarding their health. This study is similar to the study of Chronic Non-Communicable Diseases among the Elderly in Bangladesh Old Age Homes ${ }^{16}$. Most of the respondents had to go to hospital when they were sick. So, there is lack of separate clinic room in most of the old aged homes. Further there is also lack of residential or full time health workers in all the old aged homes since most of the elderly people have at least some diseases. Regarding the drinking water, most of the elderly were getting water directly from tap, so there is lack of regular availability of hot waters at least for drinking purpose. It may cause water-borne diseases to the elderly. Most of the respondents were feeling the need of care givers for them. So, the elderly homes should have more care givers so that elderly people whenever needed may get the care from them. More than two fifth of the respondents were feeling stress in old aged homes. All the respondents prayed god to cope with the stress followed by listening to religious hymns, go to religious places, solitary living, shares the feelings to mates, crying alone, and take cigarettes/alcohols. The elderly homes should have strict rules that no one is allowed to consume alcohols and smoke cigarettes. Otherwise, it may harm the health of the elderly people and make the environment of elderly home unhealthy. They must explore some awareness program regarding the effects of smoking cigarettes and consuming alcohols. More than four fifth of the respondents responded that they had different types of mind diversional activities launched by the elderly home like religious hymns and the elderly homes arranged the different types of activities like visit to religious places, celebration of festivals, celebration of birthday ceremony of different people visiting elderly home which helped to divert their mind from feeling of stress. This result is also similar to the study of Dhungana in Pokhara Briddhashram, Pokhara. ${ }^{14}$

\section{LIMITATION OF THE STUDY}

This study is limited only on the chronic physical health problems of the elderly people. Other demographic and economic factors such as income, family status, place of origin, reasons behind choosing elderly homes are excluded in this article.

\section{CONCLUSION}

The elderly people were suffered from at least one chronic physical health problems. Hence, the health status of the elderly people living in old aged homes was not good. Female were more vulnerable than male regarding the chronic physical health status.

\section{REFERENCES}

1. Old Age Home And Child Care Home Project. Nepali Host Family, volunteer.explore Nepal. [Link]

2. Central Bureau of Statistics. Population census 2001, National Report. Kathmandu: His Majesty's Government National Planning Commission Secretariat, 2002. [Full Text]

3. Central Bureau of Statistics. Population monograph of Nepal 2003, Volume 1. Kathmandu: His Majesty's Government National Planning Commission Secretariat, 2003. [Full Text]

4. Central Bureau of Statistics. Population monograph of Nepal. Kathmandu: His Majesty's Government National Planning Commission Secretariat, 1995. [ull Text]

5. Central Bureau of Statistics. Population monograph of Nepal 2014, Volume II. Kathmandu: Government of Nepal, National Planning Commission Secretariat, 2014. [Full Text]

6. Dahal BP. Elderly people in Nepal what happened after MIPPA, 2002? A report for Economic and Social Commission for Asia and the Pacific Macao, China, October 2007. [Full Text] 
7. Lucas PM. Old Age Pension as a Social Security Initiative : The Case Of Botswana. 2009; University Of Botswana. [Full Text]

8. Singh P, Kumar K, Reddy PK. Psychiatric morbidity in geriatric population in old age homes and community: a comparative study. Indian Journal of Psychological Medicine 2012;34(1):39-43. https://doi. org/10.4103/0253-7176.96157 [Full Text]

9. Saha SS, Saha PK. An Epidemiological study on Depression and related factors among Geriatrics in a tertiary care Hospital. Journal of Dental and Medical Sciences 2013;12(6):1417. https://doi.org/10.9790/0853-1261417 [Full Text]

10. Ho RC, Ho EC, Tai BC, Ng WY, Chia BH. Elderly suicide with and without a history of suicidal behavior: implications for suicide prevention and management. Archives of suicide research 2014;18(4):363-375. https:// doi.org/10.1080/13811118.2013.826153 [Full Text]

11. Mehrotra N, Batish S. Assessment of problems among elderly females of Ludhiana city. Journal of Human Ecology 2009;28(3):213-216. https:// doi.org/10.1080/09709274.2009.11906242 [Full Text]
12. Etemadi A, Ahmadi K. Psychological disorders of elderly home residents.

Journal of Applied Sciences 2009;9:549-554. https://doi.org/10.3923/jas.2009.549.554

13. Singh A, Kaushal SK, Misra SK, Agrawal R. Depression and religiosity among urban elderly population of western Uttar Pradesh, India. Int $\mathrm{J}$ Community Med Public Health 2018;5:1570-4.https://doi.org/10.18203/23946040.ijcmph20181235

14. Dhungana AR. Health Practices of Elderly People Living in Pokhara Briddhashram, Pokhara. Journal of Development and Social Engineering 2014;1(1):65-73.

15. Kleisiaris C, Papathanasiou I, Tsaras K, Androulakis E, Kourkouta L, Fradelos E, Zyga S. Factors Affecting the Health Status of Elderly People Receiving Home Care. Archives of Hellenic Medicine 2019; 36(2):237-244. Available at

16. Taskin T, Biswas T, Siddiquee AT, Islam A, Alam D. Chronic Non Communicable Diseases among the Elderly in Bangladesh Old Age Homes. The International Journal of Aging and Society 2014; 3(4):67-75. https://doi. org/10.18848/2160-1909/CGP/v03i04/35125 [Full Text] 